was believed, on morphological and other grounds, that each represented a single storile clone of hybrid origin. If this supposition were correct, any major differences in terpene content between herbarium material could be put down to ageing effects rather than genetic heterogeneity.

Both $M$. alopecuroides and $M$. citrata are widely cultivated plants which are occasionally found as garden escapes; and both are known to have been in existence for at least two hundred years.

Typical traces from four different specimens of $M$. alopecuroides are illustrated. The samples were run under identical conditions, although increased amplification was necessary in some cases, because of loss of essential oil with age. 'The similarity of the four traces is at once obvious. Specimens $A$ and $B$ (for further details see the figure) are both of recent origin and do not differ in terpene content from fresh material. They were collected in different years from different localities, and yet their traces are almost identical. The similarity is eloser than that among the progeny from selfing $M$. spicata. Specimen $C$ was collected in 1893 and specimen $D$ in about 1798 by William Sole, although the specimen is undated. The Department of Botany at the University of Bristol is very fortunate in possessing a set of Sole's exsiccata of mints which follows the arrangement and nomenclature of his monograph Menthae Britannicae published in 1798.

These older specimens nevertheless have traces which are at once closcly comparable with the more modern ones. Until the individual peaks have been identified, a detailed comparison is perhaps not justified, but attention is drawn to two points.

Peaks 1 and 2 are only visible on the oldest trace because of the much greater amplification. On increasing the amplification of $A, B$ and $C$, peaks 1 and 2 at once appear. Peaks 5, 6 and 7 are clearly the least stable components on ageing, but their changes do not unduly affect the diagnostic value of the trace.

From these results, it seoms very likely that $M$. alopecuroides, at least as ropresented by the plants so far examined, is a single clone. A similar conclusion was reached in the case of $M$. citrata, which also produced a series of almost identical traces, though much more material remains to be examined.

In the case of $M$. spicata itself we have evidence for a similar recurrence of cortain clones in the material we have examined. Not only does the presont technique offer considerable scope in experimental taxonomic and population investigations, but it also seems to be of value in the correct identification of old or fragmentary herbarium material, particularly where this affects typification, and where the material cannot be identified by more orthodox means. A caso in point is Linnaeus' type specimen of $M$. aquatica, which may well be of hybrid origin. Gas chromatographic analysis should be able to solve this and similar problems.

One of us (M. G. B.) acknowledges the tenure of a Unilever research assistantship held during the course of this work.

R. M. Hakley M. G. BeLL

Department of Botany,

University of Bristol.

\section{Effect of Ectopic Pituitary Grafts on the Olfactory Block to Pregnancy in Mice}

THE neuro-endocrine cause of the alien male-induced pregnancy block in newly mated female mice ${ }^{1,2}$ is the failure of prolactin (luteotrophin) secretion by the adenohypophysis with consequent failure of the development of the corpora lutea and the roturn of the females to oestrus as if mating had not occurred. Administration of oxogenous prolactin ${ }^{1}$ or the increased secretion of prolactin induced by suckling in lactating females ${ }^{3}$ would prevent the block in newly mated females kept near to alien males. It is now clearly established that the pheromones which cause the pregnancy block aro excreted in the urine of maile mice ${ }^{4}$. Hypophysial grafts to an ectopic site are known to secrete prolactin continuously ${ }^{5,6}$ and so we investigated the effects of such grafts in newly mated fomale mice exposed to urine fro, n alien males.

All the females and the stud males were outbred albinos of the Parkes stock. Females were about 10 weeks old at the start of the experiment. Each intact female received a graft of the adenohypophysis from a donor female of the same age. The graft was placed in the subcapsular space of the right kidnoy. The external indication of a functioning ectopic pituitary graft in the intact female mouse is the appearance of a series of pseudopregnancy. like cycles ${ }^{6}$. After two or throe consecutive pseudopregnancy-like cycles in each female, shown by daily examination of a vaginal smear, they were paired with the stud male. When the vaginal plug was found (day 0 ), the female was separated from the stud male and housed singly. About 5-7 weeks elapsed between the grafting of the pituitary and mating of the female. Twenty-four hours after mating (day 1 of pregnancy), the female was exposed to fresh urine from twelve inbred $C B A$ males, as described elsewhore ${ }^{4}$, for 3 days. A control group bearing no ectopic pituitary grafts, that is, unoperated, was mated and similarly exposed to urine from males for 3 days. Normal femalos were used as controls because mock operation of the females or the placing of a piece of the brain tissue in their kidney capsules in no way modified the oestrous cycles. Another group of females was mated and left undisturbed after separation from the stud male in order to assess the rato of spontaneous failure of pregnancy. Daily vaginal smears were examined from all females up to day 7 post coitum and a return of oestrus during this period was considered to be the external manifestation of pregnancy failure ${ }^{2}$. The results are summarized in Table 1 .

Table 1. INHibition OF PREgNANCY BLOCK IN NEWLY MATED MICE BY OF PREGAANCY BLOCK IN

\begin{tabular}{|c|c|}
\hline $\begin{array}{l}\text { Proportion and } \\
\text { ercentage of females } \\
\text { returning to } \\
\text { oestrus }\end{array}$ & $\begin{array}{l}\text { Proportion and } \\
\text { percentage of females } \\
\text { remaining pregnant } \\
\text { or pseudo-pregnant }\end{array}$ \\
\hline $11^{\prime} 64(17 \%)^{*}$ & $53 / 64(83 \%)$ \\
\hline $\begin{array}{c}45 / 52(87 \%)^{*} \\
2 / 20(10 \%)\end{array}$ & $\begin{array}{r}7 / 52(13 \%) \\
18 / 20(90 \%)\end{array}$ \\
\hline
\end{tabular}

(B. males a ectople pituitary graft Undisturbed $* P<0.001$ $2 / 20(10 \%)$ $18 / 20(90 \%)$

It is evident that the ectopic pituitary graft removed from neural control and hence from the olfactory influence could prevent the male-induced pregnancy block from taking place in a large proportion of newly mated fomales. Obviously the prolactin secreted by the pituitary graft could sustain the corpora lutca over the period when the luteotrophic activity of the female's own pituitary was temporarily suspended. Thus, the inhibition of the pregnancy block in females exposed to urine from males by ectopic pituitary graft provides additional evidence in support of the view ${ }^{1}$ that the block is caused by the failure of the luteotrophic function of the anterior pituitary.

I thank Professor A. S. Parkes and Miss H. M. Bruce for suggestions and the Population Council and the Ford Foundation for financial support.

Physiological Laboratory,

C. J. Dominic*

University of Cambridge.

* Present address: Department of Zoology, Banaras Hindu University, Varanasi 5, India.

' Parkes, A. S., Proc. Fourth Int. Congr. Anim. Reprod., 163 (1961).

2 Bruce, II. M., J. Reprod. Fert., 1, 96 (1960).

${ }^{3}$ Bruce, H. M., and P'arkes, A. S., J. Endorrinol.,22, 6 (1961).

4 Dominic, C. .T., J. Reprod. Fert.,11, 407 (1960).

"Harris, G. W. Neural Control of the Pituitary Gland (Edward Arnold Londis, G. W.
Lon, 1955).

s. Muhlbock, O., and Boot, I. M., Cancer Res., 18, 402 (1959). 